\title{
The Influence of Season Variation on Hematological Parameters and Oxidative Stress for Rainbow Trout (Oncorhynchus mykiss)
}

\author{
Andrada IHUȚ, Camelia RĂDUCU, Călin LAŢIU, Daniel COCAN, Paul UIUIU, Vioara MIREŞAN* \\ Faculty of Animal Science and Biotechnologies, University of Agricultural Sciences and Veterinary \\ Medicine, 3-5 Mănăștur Street, 400372 Cluj-Napoca, Romania \\ *corresponding author: vmiresan@yahoo.com; vioara.miresan@usamvcluj.ro
}

Bulletin UASVM Animal Science and Biotechnologies 75(1)/ 2018

Print ISSN 1843-5262; Electronic ISSN 1843-536X

DOI:10.15835/buasvmcn-asb: 003517

\begin{abstract}
The parameters studied were $\mathrm{RBC}, \mathrm{Ht}, \mathrm{Hb}$, erythrocyte index $\mathrm{MCV}, \mathrm{MCH}, \mathrm{MCHC}$, and oxidative stress through SOD and GPx. For each parameter, blood samples were collected at specimens weighing between 100-140g in the summer season, 250-280 g in the fall, 270-300g in the winter and 320-350g in the spring. At the specimens studied the highest values of GPx and SOD were recorded in the spring season due to the stress caused by massive precipitation. During the study, the water temperature ranged between $5.1^{\circ} \mathrm{C}$ in winter and $19.2^{\circ} \mathrm{C}$ in summer and $\mathrm{O}_{2}$ ranged between $8.30 \mathrm{mg} / \mathrm{l}$ in the summer and $10.20 \mathrm{mg} / \mathrm{l}$ in winter. For most parameters, the highest values were recorded in the spring season and the lowest in the summer season. The data obtained in each season on Oncorhynchus mykiss species do not indicate pathological conditions but more an adaptive fish response to environmental conditions and can serve as a database for future research on welfare of salmonids.
\end{abstract}

Keywords: antioxidant, alimentary behavior, hematological parameters

\section{INTRODUCTION}

Fish like other species have an antioxidant defense system (Cristina Trenzado et al., 2006) which is subject to change by alimentary behavior, phylogeny, age, water chemical composition and physiological condition (Martínez-Álvarez et al., 2005). From physiological point of view the level of oxidative stress and hematological parameters gives us useful information in detection and diagnosis of metabolic dysfunctions. As well according to Aldrin and Smith (1975) we can appreciate the state of health, nutrition, stress response and adaptability to environmental conditions. Also, Ates et al., (2008) sustained that fish biochemical analyses and hematological parameters can be used as sensitive biomarkers for monitoring of water quality before negative effects to appear in the aquatic environment.

\section{MATERIALS AND METHODS}

In every season (summer, autumn, winter and spring) were taken randomized from growing pool 10 specimens of rainbow trout (Oncorhynchus mykiss) from which we collected blood from kidney to evaluate the oxidative stress and hematological changes. The research took place in Bistrisorii Valley, Bistra, Alba County beginning with the summer of 2014 till the spring of 2015.

The hematological parameters included the count of RBC, $\mathrm{Hb}, \mathrm{Ht}$ from whole blood into an anticoagulant (Li heparin) in vacutainers of $5 \mathrm{ml}$.

Erythrocytes count was made with the Gowers reagent, through a turbidimetrically reaction discernible to a wavelength of $\lambda=546 \mathrm{~nm}$ and at a temperature of $37^{\circ}$ degrees.

Hemoglobin was dosed within 6 hours from harvesting, through a calorimetrical END -POINT 
Table 1. The mean values of hematological parameters on four seasons of rainbow trout (Oncorhynchus mykiss)

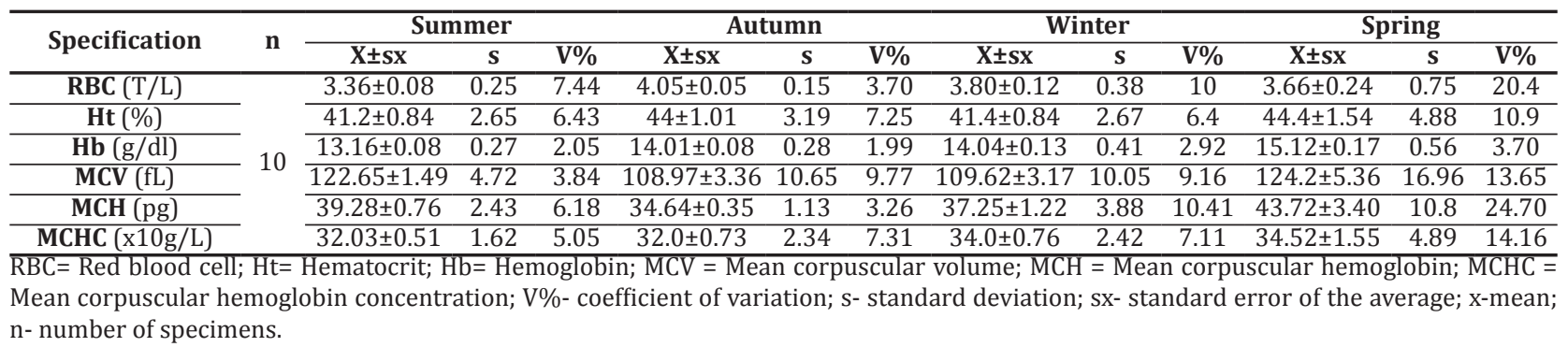

reaction, read in the VIS domain at $\lambda=546 \mathrm{~nm}$ and at a temperature of $37^{\circ}$ degrees.

The hematocrit through centrifugation was dosed from whole blood into capillary tubes at $12.000 \mathrm{rpm}$ for 3 minutes and on a graduated scale there is the high of the erythrocytes column, indicated in percent (\%) of volume.

Erythrocyte indices MCV (fL), MCH (pg) and MCHC $(\mathrm{x} 10 \mathrm{~g} / \mathrm{L})$ were determined throughout calculates formulas in conformity with Ghergariu et al., (1999).

All the analyses were performed with the UV-VIS spectrophotometer, Screen Master Touch, which works in 340-620 nm wavelengths. The oxidative stress was determined based on the antioxidant enzyme GPx and SOD according to the protocol (Ghergariu et al., 1999; Kádár, 2002).

Statistical calculation was made with GraphPad Prism 6 software. Bonferroni test was used for processing data, this test performed a comparison of hematological parameters depending on the season, obtaining the value of the probability index " $p$ ". The statistical validity of the data obtained by the Tukey test was verified by applying normality tests involving the calculation of the Kolmogorov-Smirnov index (Motulsky et al., 1999; Motulsky, 2004).

\section{RESULTS AND DISCUSSIONS}

As regards the fishes, RBC's are the most numerous blood cells, up to 4 million/mm3 (Nicula et al., 2004) which contains hemoglobin involved in oxygen delivery from gills to tissues. Fishes erythrocytes are usually mononuclear with different sizes depending on the species (Snyder et al., 1999), on the active ones like the rainbow trout, the dimensions are bigger compared with the sedentary ones since they need a bigger amount of oxygen (Cocan, 2011). Within our research the average values of the RBC are in Table 1 and differences between seasons in Table 2 .

According to Sonia Mumford et al., (2007), the increase of the RBC number is due to the enhancing of the hematopoietic system from the apical segment pole of the kidney, under the circumstances of temperature rise. However, in the case of our research, the highest values were recorded in the spring season when the water temperature was $10.2^{\circ} \mathrm{C}$ and not in the summer season when the water temperature was $19.2^{\circ} \mathrm{C}$. This can be attributed due to the adaptability of rainbow trout to different environmental condition, the species developed a mechanism of hemoglobin regulation without having the need for an increase of hematopoiesis. And even if RBC values were lower in the summer, differences between seasons were not significant except for the autumn season. However as stated by Rahman et al., (2013), this can be also influenced by the body weight or by the photoperiod (Solomon and Okomoda, 2012).

Ht value is used to establish the erythrocyte index, and along with these, in conformity with Pârvu et al., (1984), in diagnose different anemias. According to Lientz and Smith (1974) Ht value are positively correlated with the weight of the fish and it can be influenced by its density of breeding as stated by Yarahmadi et al., (2014). The values we obtained regarding the species Oncorhynchus mykiss can be placed between the limits quoted by Fazio et al., (2016) which are $20-43 \%$. Within our research Ht value at the rainbow trout did not present variations between seasons and the average values for each season are presented in Table 1 and 2. The obtained results fall within the limits quoted by Ates et al., (2008), Cocan et al., (2011) and Yldiz and Aydin (2006), with the specification that our values are for the same season and for the same fish population. 
Table 2. Differences between seasons and their statistical significance on hematological parameters of rainbow trout (Oncorhynchus mykiss)

\begin{tabular}{ccccccccccccc}
\hline \multirow{2}{*}{ Specification } & \multicolumn{2}{c}{$\begin{array}{c}\text { Summer - } \\
\text { Autumn }\end{array}$} & \multicolumn{2}{c}{$\begin{array}{c}\text { Summer - } \\
\text { Winter }\end{array}$} & \multicolumn{6}{c}{ Summer - Spring Autumn - Winter Autumn - Spring Winter - Spring } \\
\cline { 2 - 13 } & $\mathbf{d}$ & $\mathbf{t}$ & $\mathbf{d}$ & $\mathbf{t}$ & $\mathbf{d}$ & $\mathbf{t}$ & $\mathbf{d}$ & $\mathbf{t}$ & $\mathbf{d}$ & $\mathbf{t}$ & $\mathbf{d}$ & $\mathbf{t}$ \\
\hline $\mathbf{R B C}(\mathrm{T} / \mathrm{L})$ & $-0.68^{* *}$ & 3.76 & $-0.43 \mathrm{~ns}$ & 2.41 & $-0.29 \mathrm{~ns}$ & 1.63 & $0.24 \mathrm{~ns}$ & 1.35 & $0.38 \mathrm{~ns}$ & 2.13 & $0.14 \mathrm{~ns}$ & 0.78 \\
\hline $\mathbf{H t}(\%)$ & $-2.80 \mathrm{~ns}$ & 1.72 & $-0.20 \mathrm{~ns}$ & 0.12 & $-3.20 \mathrm{~ns}$ & 1.97 & $2.60 \mathrm{~ns}$ & 1.60 & $-0.40 \mathrm{~ns}$ & 0.24 & $-3.00 \mathrm{~ns}$ & 1.85 \\
\hline $\mathbf{H b}(\mathrm{g} / \mathrm{dl})$ & $-0.85^{* * *}$ & 5.06 & $-0.88^{* * *}$ & 5.24 & $-1.96^{* * *}$ & 11.67 & $-0.03 \mathrm{~ns}$ & 0.178 & $-1.11^{* * *}$ & 6.61 & $-1.08^{* * *}$ & 6.43 \\
\hline $\mathbf{M C V}(\mathrm{fL})$ & $13.68^{*}$ & 2.95 & $13.03 \mathrm{~ns}$ & 2.81 & $-1.55 \mathrm{~ns}$ & 0.33 & $-0.64 \mathrm{~ns}$ & 0.14 & $-15.23^{*}$ & 3.28 & $-14.58^{*}$ & 3.14 \\
\hline $\mathbf{M C H}(\mathrm{pg})$ & $4.64 \mathrm{~ns}$ & 1.84 & $2.03 \mathrm{~ns}$ & 0.805 & $-4.44 \mathrm{~ns}$ & 1.77 & $-2.61 \mathrm{~ns}$ & 1.04 & $-9.08^{* *}$ & 3.61 & $-6.47 \mathrm{~ns}$ & 2.57 \\
\hline $\mathbf{M C H C}(\mathrm{x} 10 \mathrm{~g} / \mathrm{L})$ & $0.04 \mathrm{~ns}$ & 0.02 & $-2.00 \mathrm{~ns}$ & 1.38 & $-2.49 \mathrm{~ns}$ & 1.72 & $-2.05 \mathrm{~ns}$ & 1.41 & $-2.54 \mathrm{~ns}$ & 1.75 & $-0.48 \mathrm{~ns}$ & 0.33 \\
\hline
\end{tabular}

$\mathrm{RBC}=$ Redblood cell; $\mathrm{Ht}=$ Hematocrit; $\mathrm{Hb}=$ Hemoglobin; $\mathrm{MCV}=$ Mean corpuscular volume; $\mathrm{MCH}=$ Mean corpuscular hemoglobin; $\mathrm{MCHC}=$ Mean corpuscular hemoglobin concentration; $\mathrm{d}=$ the difference between seasons; $\mathrm{t}=$ the value of $\mathrm{t}$; ${ }^{*}=\mathrm{p}<0.05$ significant; ${ }^{* *}=\mathrm{p}<0.01$ distinctly significant; ${ }^{* * *}=\mathrm{p}<0.001$ very significant; $\mathrm{ns}=$ insignificant;

Table 3. The mean values of glutathione peroxidase (GPx) and superoxide dismutase (SOD) on four seasons of rainbow trout (Oncorhynchus mykiss)

\begin{tabular}{|c|c|c|c|c|c|c|c|}
\hline \multirow{2}{*}{ Specification } & \multirow{2}{*}{$\mathbf{n}$} & \multicolumn{3}{|c|}{ Glutathione peroxidase U/gHb } & \multicolumn{3}{|c|}{ Superoxide dismutase U/gHb } \\
\hline & & $\mathrm{X} \pm \mathrm{SX}$ & $\mathbf{S}$ & V\% & $\mathrm{X} \pm \mathbf{s X}$ & $\mathbf{S}$ & V\% \\
\hline Summer & \multirow{4}{*}{10} & $72.90 \pm 1.11$ & 3.53 & 4.84 & $914.9 \pm 26.21$ & 82.89 & $\overline{9.06}$ \\
\hline Autumn & & $79.56 \pm 0.82$ & 2.60 & 3.27 & $865.9 \pm 23.53$ & 74.41 & 8.59 \\
\hline Winter & & $91.84 \pm 2.75$ & 8.72 & 9.49 & $841.1 \pm 18.18$ & 57.50 & 6.84 \\
\hline Spring & & $95.54 \pm 3.41$ & 10.79 & 5.19 & $919.4 \pm 8.86$ & 28.02 & 5.54 \\
\hline
\end{tabular}

The hemoglobin contains approximately 80$90 \%$ from the dry substance of the erythrocytes at the rainbow trout, meaning $7 \mathrm{~g} / 100 \mathrm{ml}$ with variations between $4.1-10.3 \mathrm{~g} / \mathrm{dl}$, according to Pârvu et al., (1984).

Its value may present differences depending of species, season, forage given, age etc. In our research, the $\mathrm{Hb}$ value ranged from $13.16 \pm 0.08 \mathrm{~g} /$ $\mathrm{dl}$ in summer and $15.12 \pm 0.17 \mathrm{~g} / \mathrm{dl}$ in spring. Thus, resulting very significant differences among the seasons summer-autumn $d=-0.85$, summer-winter $d=-0.88$, summer-spring $d=-1.96$, autumn-spring $\mathrm{d}=-1.11$ and winter-spring $\mathrm{d}=-1.08$. The values we obtained are bigger than Cocan et al., (2011) which were $7.42-11.32 \mathrm{~g} / \mathrm{dl}$ for the same species.

Mean corpuscular volume (MCV) represents the volume filled with only one erythrocyte, whose analysis helps in identify precocious anemias as well as in their classification. MCV value is influenced by the age of the fish that is why in the case of samplings the hematopoiesis tissues change and the organs such as the spleen and the kidney keep developing (Lone et al., 2012; Rijkers and Muiswinkel, 1977). In what our research is concerned, the MCV presented the highest values in spring $124.2 \pm 5.36 \mathrm{fl}$ and in summer $122.65 \pm 1.49 \mathrm{fl}$ and the lowest in autumn
$124.2 \pm 5.36 \mathrm{fl}$ and $109.62 \pm 3.17 \mathrm{fl}$ during winter, leading to significant differences between seasons: summer-autumn $d=13.68$, autumn-spring $d=-$ 15.23 and winter-spring $d=-14.58$. MCV values were positively correlated with the temperature and they were higher than $88 \mathrm{fl}$ cited by Lone et al., (2012) for the same species.

In terms of the $\mathrm{MCH}$ values the lowest were during autumn $34.64 \pm 0.35 \mathrm{pg}$ and winter $37.25 \pm 1.22 \mathrm{pg}$ and the highest in spring $43.72 \pm 3.40$ pg and summer $39.28 \pm 0.76 \mathrm{pg}$. In this way a significant difference resulted between autumn and spring of $\mathrm{d}=-9.08$. In accordance with Lone et al., (2012) the MCH value is influenced by the age of the fish that is why in the case of rainbow Trout saplings it is between $18-25 \mathrm{pg}$, and at the adult fish is $58.49 \mathrm{pg}$. As stated by Wedekind and Schreckenbach (2003) the MCH values influenced by the water temperature and Yarahmadi et al., (2014) claims that it depends on the density of breeding. The values we obtained can be placed between the limits quoted by Fazio et al., (2016), meaning 23.16-68.06 pg. The Concentration of red blood cell hemoglobin (MCHC) includes values within $32.03 \pm 0.51(\mathrm{x} 10 \mathrm{~g} / \mathrm{L})$ in summer and $34.52 \pm 1.55(\mathrm{x} 10 \mathrm{~g} / \mathrm{L})$ in spring, situated between the limits cited by Yarahmadi et al., (2014). 
Table 4. Differences between seasons and their statistical significance on oxidative stress by glutathione peroxidase (GPx) and superoxide dismutase (SOD) of rainbow trout (Oncorhynchus mykiss)

\begin{tabular}{lllll}
\hline \multirow{2}{*}{ Season } & \multicolumn{2}{c}{ Glutathione peroxidase U/gHb } & \multicolumn{2}{c}{ Superoxide dismutase U/gHb } \\
\cline { 2 - 5 } & $\mathbf{d}$ & $\mathbf{t}$ & $\mathbf{d}$ & $\mathbf{t}$ \\
\hline Summer - Autumn & $-6.66 \mathbf{n s}$ & 2.04 & $49.00 \mathbf{n s}$ & 1.70 \\
\hline Summer - Winter & $-18.94^{* * *}$ & 5.82 & $73.72 \mathbf{n s}$ & 2.56 \\
\hline Summer - Spring & $-22.64^{* * *}$ & 6.96 & $-4.58 \mathbf{n s}$ & 0.15 \\
\hline Autumn - Winter & $-12.28^{* *}$ & 3.77 & $24.72 \mathbf{n s}$ & 0.86 \\
\hline Autumn - Spring & $-15.98^{* * *}$ & 4.91 & $-53.58 \mathbf{n s}$ & 1.86 \\
\hline Winter - Spring & $-3.70 \mathbf{n s}$ & 1.13 & $-78.30 \mathbf{n s}$ & 2.72 \\
$\begin{array}{l}\text { d= the difference between } \\
\text { insignificant; }\end{array}$ & seasons; $\mathrm{t}=$ the value of $\mathrm{t} ;{ }^{* *}=\mathrm{p}<0.01$ distinctly significant; ${ }^{* * *}=\mathrm{p}<0.001$ very significant; ns \\
\end{tabular}

Such as aerophiles organisms, the fish have an antioxidant defense system (Cristina Trenzado et al., 2006) being influenced by the alimentary behavior, phylogeny, age, chemical composition of the water and physiological condition (MartínezÁlvarez et al., 2005). In the Table 3, medium values and the variability of the GPx (Glutathione peroxidase) and SOD (superoxide dismutase) are presented for each season, and in Table 4 there are presented the statistic differences of those between seasons.

As regards the glutathione peroxidase (GPx), these are protecting the proteins and the nucleic acids from the action of the oxidative molecules, and its quantity might be found in bigger proportion than in SOD and the values of these metalloenzymes might vary depending on the zone they were collected (heart, liver, kidney, muscles, etc.). In our research the GPx values between seasons were: influenced by the water temperature and it is situated in the limits cited by Cocan (2011) for the same species of $43.77 \mathrm{U} / \mathrm{gHb}$ during winter and $116.53 \mathrm{U} / \mathrm{gHb}$ during summer.

Superoxide dismutase (SOD) of rainbow trout is the first enzyme which acts against oxygen radicals (Mccord and Fridovich, 1969) which gives the best answer at oxidative stress (Winston and Giulio, 1991). As expected, the lower values were recorded in the winter cold season and the highest during summer and spring when there was plentiful precipitation which slightly changed the water chemical composition. The values we obtained are higher than what Trenzado et al., (2006) had for this species Oncorhynchus, of $834.69 \mathrm{U} / \mathrm{gHb}$ and lower than $1309.9 \mathrm{U} / \mathrm{gHb}$ quoted by Cocan (2011) in summer on rainbow trout.

\section{CONCLUSIONS}

The values of hematological parameters and oxidative stress presented variations among the 4 seasons, interpreted as being the adaptability reaction of the fish at the environmental conditions.

Future research is needed for other species of salmonids with the purpose to offer a database that can be used in monitoring the physiological status of the fish as well as aquatic environment to have a more efficient fishery production.

Acknowledgments. This paper was published under the frame of European Social Fund, Human Resources Development Operational Programme 2007-2013, project no. POSDRU/159/1.5/S/132765.

\section{REFERENCES}

1. Aldrin DF, Smith L (1975). Pathophysiology of infectious hematopoietic necrosis virus disease in Rainbow Trout. Hematological and blood chemical changes in moribund fish. Infectious Immunology, 1: 171-179.

2. Ates B, Orun I, Talas ZS, Durmaz G, Yilmaz I (2008). Effects of sodium selenite on some biochemical and hematological parameters of rainbow trout (Oncorhynchus mykiss Walbaum, 1792) exposed to $\mathrm{Pb}^{2+}$ and $\mathrm{Cu}^{2+}$, Fish Physiology Biochemistry, 34: 53-59.

3. Cocan D (2011). Particularităţi morfo-fiziologice ale Păstrăvului curcubeu în diferite sisteme de creștere şi exploatare. Teză de doctorat USAMV Cluj Napoca.

4. Fazio F, Saoca C, Piccione G, Kesbiç OS, Acar Ü (2016). Comparative study of some hematological and biochemical parameters of Italian and Turkish farmed Rainbow Trout Oncorhynchus Mykiss (Walbaum, 1792). Journal of Fisheries and Aquatic Sciences, 16: 715-721.

5. Ghergariu S, Laszlo K, Pop A, Spanu M, (1999). Manual de laborator clinic veterinar, Timisoara, Editura All.

6. Kádár L (2002). Investigații Biochimice în Laboratorul Clinic Veterinar. Editura Academicpress. 
7. Lientz JC, Smith CE (1974). Some haematological parameters for hatchery-reared cutthroat trout. The Progressive Fish-Culturist, 36: 49-50.

8. Lone GN, Shammi QJ, Mir SA, Sheikh IA, Chalkoo SR (2012). Rainbow Trout Hematology Coinciding with Metabolic Requirement. Walailak Journal of Science and Technology, 9: 309-316.

9. Martínez-Álvarez RM, Morales AE, Sanz A (2005). Antioxidant defenses in fish Biotic and abiotic factors. Reviews in Fish Biology and Fisheries, 15: 75-88.

10. Mccord JM, Fridovich J (1969). Superoxide dismutase an enzymatic function for erythrocuprein (hemocuprein). Journal Biol. Chem. 244: 6049-6055.

11. Motulsky HJ, (2004) Analyzing data with GraphPad prism, GraphPad Software, Inc, USA.

12. Motulsky HJ, Platt M, Pilkington J (1999). Guide to choosing and interpreting statistical tests, GraphPad Software, Inc, USA.

13. Mumford S, Heidel J, Smith C, Morrison J, Macconnell B, Blazer V (2007). Fish Histology and Histopathology manual. USFWS-NCTC.

14. Nicula M (2004). Fiziologia Organismelor Acvatice Vol I. Fiziologia peștilor. Ed. Mirton Timișoara.

15. Pârvu G, Barna I, Căprărin A (1984). Hematologie veterinară practică. Ed. Ceres București.

16. Rahman MAU, Khan A, Lyla PS, Kadharsha K, Chander PM, John BA (2013). Length-weight relationship and condition factor of Liza subviridis (Valenciennes, 1836) of Parangipettai Waters Southeast Coast of India. Pakistan Journal of Biology Sciences, 16: 345-350.

17. Rijkers GT, Muiswinkel WB (1977). The immune system of Cyprinid fish. The development of cellular and humoral responsiveness in the rosy barb (Barbus conchonius). Developmental Immunobiology. Solomon J.B. Horton J.D.

18. Solomon SG, Okomoda VT (2012). Effects of Photoperiod on the Haematological Parameters of Clarias Gariepinus Fingerlings reared in recirculatory water system. Journal of Stress Physiology and Biochemistry, 8: 247-246.

19. Trenzado CM, Hidalgo C, García-Gallego M, Morales AE, Furné M, Domezain A, Domezain J, Sanz A (2006). Antioxidant enzymes and lipid peroxidation in sturgeon Acipenser naccarii and trout Oncorhynchus mykiss. A comparative study. Aquaculture, 254: 758-767.

20. Wedekind H, Schreckenbach K (2003). Investigations on the effect of angling on stress response in rainbow trout. Bulletin of the European Association of Fish Pathologists, 23: 235-240.

21. Winston GW, Giulio Di RT, (1991). Prooxidant and antioxidant mechanisms in aquatic organisms. Aquatic Toxicology, 19: 137-161.

22. Yarahmadi P, Miandare HK, Hoseinifar SH, Gheysvandi $\mathrm{N}$, Akbarzadeh A (2014). The effects of stocking density on hemato-immunological and serum biochemical parameters of rainbow trout (Oncorhynchus mykiss). Aquaculture International, 23: 55-63.

23. Yildiz H, Aydin S (2006). Pathological Effects of Arcobacter Cryaerophilus Infection in Rainbow Trout (Oncorhynchus Mykiss Walbaum). Acta Veterinaria Hungarica, 54:191199. 